\title{
Embriogenesis Somatik Jeruk Keprok (Citrus reticulata L. cv Batu 55) Asal Hasil Perlakuan Kolkisin
}

\author{
Somatic Embryogenesis of Mann Citrus (Citrus reticulata L. cv Batu 55) from Callus \\ Derived from Colchicine Treatment
}

\author{
Agus Purwito $^{1^{*}}$, Mohamad Prayogi ${ }^{1}$, Mia Kosmiatin ${ }^{2}$ dan Ali Husni ${ }^{2}$
}

Diterima 27 Agustus 2015/Disetujui 18 November 2015

\begin{abstract}
The objective of this study was to obtain the best method of regeneration through somatic embryogenesis of citrus cv Batu 55 from callus resulted from in vitro polyploidization by colchicine. The experiment was conducted at the Laboratory of ICABIOGRAD, Bogor and Tissue Culture Laboratory, Department of Agronomy and Horticulture, Bogor Agricultural University from March 2014 until September 2014. This study consisted of proliferation of embryogenic callus, maturation, germination of somatic embryos, growth of shoots and roots. The research were comprised of four experiments, namely: 1). The effect of Phytagel concentration $\left(2.5,3.0,3.5\right.$ and $\left.4.0 \mathrm{~g} \mathrm{~L}^{-1}\right)$ on proliferation of embryogenic callus, with 3 replications. Each experimental unit consisted of 3 clumps of callus, 2). The effect of ABA concentration (0, 0.1, 0.3 and $\left.0.5 \mathrm{mg} \mathrm{L}^{-1}\right)$ on somatic embryo maturation with 6 replications. Each experimental unit was one culture vessel containing five somatic embryos at globular phase, 3) The effect of vitamin composition (vitamin MS and vitamin $M W)$ on germination of somatic embryo with 16 replications. Each experimental unit was one culture vessel containing four somatic embryos at cotyledonary phase, and 4) The effect $0.5 \mathrm{mg} \mathrm{L}^{-1}$ of plant growth regulators (NAA, IAA, IBA) and vitamin (MS and MW) on rooting and shoot elongation of germinated somatic embryos. Experiment was repeated five times. Each experimental unit was one culture vessel containing one plantlet as explant. All experiments were arranged as a completely randomized design. The result showed that the best concentration of Phytagel for callus proliferation was $2.5 \mathrm{~g} \mathrm{~L}^{-1}$. Maturation of somatic embryos was better when the somatic embryos were planted on medium supplemented with $A B A 0.5 \mathrm{mg} \mathrm{L}^{-1}$. The MS medium supplemented with vitamin $M S$ was better than supplemented with vitamin $M W$ for the formation of plantlets, while roots and shoots elongation of the plantlet was better when explant was planted on the MS medium supplemented with vitamins MS and IBA $0.5 \mathrm{mg} \mathrm{L}^{-1}$.
\end{abstract}

Key words: proliferation, maturation, germination, embryogenic callus, plantlet.

\section{ABSTRAK}

Penelitian ini bertujuan untuk mendapatkan metode embriogenesis somatik terbaik dari kalus Jeruk Keprok cv Batu 55 yang mendapatkan perlakuan poliploidisasi dengan kolkisin. Penelitian dilakukan di Laboratorium Balai Besar Litbang Bioteknologi \& Sumber Daya Genetik Pertanian, dan Laboratorium Kultur Jaringan, Departemen Agronomi dan Hortikultura, Institut Pertanian Bogor mulai bulan Maret 2014 hingga September 2014. Penelitian ini terdiri atas proliferasi kalus embriogenik, pendewasaan, perkecambahan embrio somatik (ES), pertumbuhan tunas dan akar. Penelitian terdiri atas empat percobaan, yaitu: 1). Pengaruh konsentrasi Phytagel (2.5, 3.0, 3.5 dan $4.0 \mathrm{~g} \mathrm{~L}^{-1}$ ) terhadap proliferasi kalus embriogenik, dengan 3 ulangan, dimana setiap satuan percobaan terdiri atas 3 klum kalus, 2). Pengaruh konsentrasi ABA $\left(0,0.1,0.3\right.$ dan $\left.0.5 \mathrm{mg} \mathrm{L}^{-1}\right)$ terhadap pendewasaan ES dengan 6 ulangan. Setiap satuan percobaan ialah satu botol kultur yang ditanam lima ES fase globular, 3) Pengaruh komposisi vitamin (vitamin MS dan vitamin MW) terhadap perkecambahan ES dengan 16 ulangan. Setiap satuan percobaan ialah satu botol kultur yang

\footnotetext{
${ }^{1}$ Departemen Agronomi dan Hortikultura, Fakultas Pertanian, Institut Pertanian Bogor (Bogor Agricultural University), Jl. Meranti Kampus Darmaga, Bogor 16680 Indonesia. Telp.\&Faks. 62-251-8629353.

${ }^{2}$ Balai Besar Litbang Bioteknologi \& Sumber Daya Genetik Pertanian, Jalan Tentara Pelajar No.3A, Bogor Barat, Jawa Barat Telp: 62-251-8337975. email: apurwito@yahoo.com. (*penulis korespondensi)
} 
ditanami empat ES fase kotiledon, dan 4) Pengaruh $0.5 \mathrm{mg} \mathrm{L}^{-1}$ zat pengatur tumbuh (NAA, IAA, IBA) dan vitamin (MS dan MW) terhadap pertumbuhan tunas dan akar pada ES yang telah berkecambah. Setiap perlakuan diulang lima kali. Setiap satuan percobaan ialah satu botol kultur yang berisi satu planlet. Seluruh percobaan disusun menggunakan rancangan acak lengkap (RAL). Hasil menunjukkan bahwa konsentrasi terbaik Phytagel untuk proliferasi kalus adalah $2.5 \mathrm{~g} \mathrm{~L}^{-1}$. Pendewasan menjadi ES fase kotiledon akan lebih baik jika ES ditanam pada medium dengan ABA $0.5 \mathrm{mg} \mathrm{L}^{-1}$. Untuk pembentukan planlet, ES fase kotiledon akan lebih baik ditanam dalam medium MS yang ditambah vitamin MS dibanding yang ditanam pada medium MS ditambah vitamin MW. Medium untuk pertumbuhan tunas dan akar terbaik adalah medium MS yang ditambah dengan vitamin MS dan IBA $0.5 \mathrm{mg} \mathrm{L}^{-1}$.

Kata kunci: proliferasi, pendewasaan, perkecambahan, kalus embriogenik, planlet.

\section{PENDAHULUAN}

Di antara tanaman buah, tanaman jeruk merupakan tanaman hortikultura yang sangat penting (Martasari, 2008). Pada umumnya tanaman jeruk dibudidayakan untuk menghasilkan buah untuk konsumsi segar (Suyamto et al., 2005). Buah jeruk di pasaran yang diminati masyarakat umumnya yang memiliki rasa manis, mudah dikupas, warna kulit buah yang menarik dan mulus, serta tanpa biji (seedless) (Martasari, 2008).

Buah tanpa biji dapat dihasilkan melalui beberapa cara, antara lain melalui mutasi, kultur endosperma (Kosmiatin et al., 2014), rekayasa genetika, fusi protoplas (Husni et al., 2010) atau melalui persilangan antara tetua diploid dengan tetua tetraploid yang akan menghasilkan tanaman triploid (Martasari, 2008). Tanaman triploid akan mengalami kegagalan dalam proses meiosis, sehingga buah yang terbentuk tidak menghasilkan biji atau menghasikan biji yang sedikit (seedless) (Yulianti et al., 2014). Tanaman jeruk tetraploid dapat dihasilkan melalui proses poliploidisasi menggunakan kolkisin, dimana kolkisin akan menginduksi terjadinya endomitosis (Chawla, 2009).

Pada penelitian sebelumnya, kalus yang dihasilkan kultur jaringan nuselus pada buah muda direndam dalam larutan kolkisin selama 3 jam dengan konsentrasi $0.1 \%, 0.2 \%$, dan $0.3 \%$. Kalus yang direndam kolkisin pada konsentrasi lebih $0.2 \%$ umumnya mengalami pencoklatan dan akhirnya mati, sedangkan kalus yang direndam kolkisin pada konsentrasi $0.1 \%$ sebagian mati dan sekitar $60 \%$ hidup. Kalus tersebut kemudian diperbanyak dan diregenerasikan melalui induksi Embrio Somatik (ES). Embriogenesis somatik merupakan metode regenerasi tanaman yang memungkinkan untuk produksi planlet dalam waktu cepat, dan tanaman yang dihasilkan berasal satu sel tunggal, sehingga dapat terhindar dari kemungkinan kimera (Agisimanto et al., 2011; Amin et al., 2015; Devy et al., 2014).

Hasil penelitian terbaru menunjukkan adanya peningkatan keberhasilan dalam pengembangan metode yang efisien dalam regenerasi in vitro melalui induksi ES tanaman jeruk (El-Sawy et al., 2013; Golami et al., 2013; Gill et al., 1995; Husain et al., 2015), akan tetapi banyak penelitian juga melaporkan adanya perbedaan metoda yang signifikan antar kultivar dan jenis eksplan yang digunakan. Penelitian Dewi et al. 2014, menunjukkan bahwa jeruk besar kultivar Nambangan dapat dikonservasi secara in vitro dengan induksi pertumbuhan minimal melalui zat pengatur tumbuh paclobutrazol dan mannitol. Metode embriogenesis somatik telah dilaporkan berhasil dengan menggunakan eksplan nuselus (Kosmiatin et al., 2015; AlTaha et al., 2011; Rangan et al., 1968), menggunakan jaringan ovul (Pasquali dan Brokoli, 2004; Starrantino dan Russo, 1980; Button dan Bornman, 1971), jus vesikel (Nito dan Iwamasa, 1990), kepala sari (Benelli et al., 2010; Hidaka et al., 1981), biji muda (Gholami, 2013), stigma (Meziane et al., 2012; Carra et al., 2006; Carimi et al., 1995) dan menggunakan jaringan akar (Gill et al., 1995). Metode regenerasi yang menggunakan eksplan jaringan nuselus umumnya memberikan hasil terbaik, namun memberikan hasil yang jelek pada spesies mono-embrioni (El-Sawy et al., 2013). Jeruk Keprok cv Batu 55 adalah spesies poli-embrioni, dimana kalus yang dipergunakan pada penelitian ini berasal jaringan nuselus (Yulianti et al., 2014), namun akan memiliki 
perbedaan dalam metode induksi ES, apalagi kalus yang diregenerasikan merupakan kalus yang berasal perlakuan kolkisin yang memungkinkan adanya keragaman jumlah kromosom.

Untuk menginduksi ES, kalus hasil perlakuan kolkisin harus disubkultur beberapa kali pada medium yang sama, sampai mendapatkan kalus embriogenik (Cardoza et al., 2002). Kalus embriogenik merupakan sel-sel meristematik yang memiliki tingkat pembelahan sel yang tinggi, kumpulan sel yang iso-diametrik, berukuran kecil dengan sitoplasma padat dengan beberapa butir pati, inti sel berukuran relatif besar dan menonjol, vakuola berukuran kecil, dinding sel tipis dan aktivitas metabolisme yang lebih tinggi (Quiroz-Figueroa et al., 2006).

Konsentrasi agar dalam media yang dipergunakan sangat mempengaruhi tujuan dilakukannya kultur jaringan untuk memperbanyak dan menginduksi kalus embriogenik. Menurut Zhang et al. (2010), jenis agar yang paling baik untuk pertumbuhan kalus embriogenik adalah Phytagel. Konsentrasi Phytagel terbaik dalam induksi kalus embriogenik adalah $2.4 \mathrm{~g} \mathrm{~L}^{-1}$ (Meneses et al., 2005). Kalus embriogenik yang dihasilkan kemudian ditanam dalam media induksi ES untuk menghasilkan ES fase globular, fase jantung dan fase terpedo (Husain et al., 2015). Embrio somatik pada fase-fase tersebut kemudian ditanam dalam media pendewasaan untuk menghasilkan ES fase kotiledon (Husain et al., 2015; Benelli et al., 2010). Asam absisat (ABA) merupakan zat pengatur tumbuh penting dalam pendewasaan ES. Tanpa ABA pendewasaan ES akan kurang berkembang dan persentase ES abnormal akan meningkat, sebaliknya ABA mendorong kualitas perkecambahan ES. Konsentrasi ABA untuk tujuan pendewasaan ES adalah sekitar $60 \mu \mathrm{M}$ ABA (Lelu et al., 1994). Untuk menghasilkan planlet, embrio fase kotiledon tersebut harus dipindahkan ke medium tertentu agar dapat berkecambah menghasilkan planlet normal yang memiliki tunas dan akar (Benelli et al., 2010). Tujuan penelitian ini adalah untuk mendapatkan planlet normal melalui induksi ES kalus yang diperlakukan kolkisin $0.1 \%$, sebagai tujuan antara untuk mendapatkan tanaman jeruk tetraploid.

\section{BAHAN DAN METODE}

\section{Bahan Percobaan}

Percobaan dilaksanakan di Laboratorium Kultur Jaringan, Kelompok Peneliti Biologi Sel dan Jaringan BB - BIOGEN, Bogor dan Laboratorium Kultur Jaringan, Departemen Agronomi dan Hortikulura, Fakultas Pertanian, IPB. Percobaan ini dilaksanakan pada bulan Maret 2014 sampai dengan bulan September 2014.

Bahan yang digunakan adalah kalus jeruk keprok Batu 55 (Citrus reticulata L.) hasil perlakuan induksi poliplodisasi dengan kolkisin. Media dasar yang digunakan adalah Murashige dan Skoog, 1962 (MS), zat pengatur tumbuh (ABA, GA, IAA, NAA, dan IBA) dan ekstrak Malt. Vitamin yang digunakan meliputi vitamin MS, dan vitamin MW (Morel dan Wetmore, 1951). Alat yang digunakan di laboratorium adalah peralatan gelas (botol kultur, botol ukur, gelas piala, cawan petri, gelas ukur, dan corong gelas), otoklaf, laminar airflow cabinet, pinset, gunting, dan scalpel, lampu spiritus, rak kultur, botol sprayer, plastik, dan karet gelang.

\section{Metode Percobaan}

Penelitian ini dilakukan dalam empat percobaan, yaitu proliferasi kalus embriogenik, pendewasaan ES, perkecambahan ES dan induksi pemanjangan tunas dan akar.

\section{Proliferasi Kalus Embriogenik}

Percobaan ini bertujuan untuk memperbanyak kalus embriogenik, sekaligus memperbanyak ES fase globular. Kalus embriogenik yang berasal percobaan poliploidisasi dengan pelakuan kolkisin $0.1 \%$ diperbanyak menggunakan media dasar MS dengan penambahan vitamin $\mathrm{MW}+$ ekstrak malt $500 \mathrm{mg} \mathrm{L}^{-1}$ dengan pemadat agar sesuai perlakuan. Percobaan ini menggunakan rancangan acak lengkap (RAL) satu faktor yaitu perlakuan konsentrasi Phytagel dengan konsentrasi $2.5 \mathrm{~g} \mathrm{~L}^{-1}, 3.0 \mathrm{~g} \mathrm{~L}^{-1}, 3.5 \mathrm{~g} \mathrm{~L}^{-1}, 4 \mathrm{~g} \mathrm{~L}^{-1}$. Setiap perlakuan diulang sebanyak 5 kali. Setiap ulangan terdiri satu botol kultur yang ditanami 3 klum kalus masing-masing berdiameter sekitar $1.0 \mathrm{~cm}$. Pengamatan dilakukan setiap minggu terhadap jumlah ES fase globular yang terbentuk. 


\section{Pendewasaan Embrio Somatik}

Tahap pendewasaan ES bertujuan untuk mendapatkan populasi ES dewasa, yaitu fase kotiledon. Pada tahap ini media yang digunakan adalah $\mathrm{MS}+$ vitamin $\mathrm{MW}+$ ekstrak malt $100 \mathrm{mg} \mathrm{L}^{-1}+$ Phytagel $2.5 \mathrm{~g} \mathrm{~L}^{-1}$ sebagai pemadat dengan perlakuan zat pengatur tumbuh ABA. Percobaan ini menggunakan rancangan acak lengkap (RAL) satu faktor, yaitu konsentrasi ABA dengan empat taraf, yatu: $0,0.1,0.3,0.5 \mathrm{mg} \mathrm{L}^{-1}$. Eksplan yang digunakan adalah ES fase globular hasil percobaan proliferasi kalus. Setiap perlakuan ABA diulang sebanyak 6 kali sehingga terdapat 24 satuan percobaan. Setiap satuan percobaan satu botol dengan 5 eksplan. Peubah yang diamati yaitu jumlah ES fase jantung, fase terpedo, dan fase kotiledon yang terbentuk.

\section{Perkecambahan Embrio Somatik}

Perkecambahan bertujuan untuk menghasilkan planlet yaitu ES yang berkecambah normal yang memiliki akar dan tunas. Pada tahap ini digunakan media MS + ekstrak malt $500 \mathrm{mg} \mathrm{L}^{-1}+\mathrm{GA}_{3} 2.5 \mathrm{ml} \mathrm{L}^{-1}$. Percobaan disusun dengan menggunakan rancangan acak lengkap satu faktor jenis vitamin yang terdiri dua taraf, yaitu vitamin MS dan vitamin MW. Setiap perlakuan vitamin diulang masing-masing sebanyak 16 kali, sehingga terdapat 32 satuan percobaan. Setiap satuan percobaan terdiri satu botol kultur dengan 4 eksplan. Eksplan yang digunakan pada tahap ini adalah ES fase kotiledon hasil percobaan pendewasaan ES. Pengamatan dilakukan terhadap peubah persentase kotiledon ES yang berakar dan berkembang menjadi planlet.

\section{Pertumbuhan Akar dan Tunas}

Percobaan pertumbuhan tunas dan akar bertujuan untuk memanjangkan tunas dan akar yang terbentuk sehingga planlet dapat diaklimatisasi. Media dasar yang digunakan adalah media MS + ekstrak malt $500 \mathrm{mg} \mathrm{L}^{-1}$, dengan penambahan jenis vitamin dan jenis auksin sesuai perlakuan. Percobaan ini adalah percobaan faktorial dengan dua faktor perlakuan. Faktor pertama adalah jenis vitamin yang terdiri dua jenis vitamin, yaitu vitamin MS dan vitamin MW, sedangkan faktor ke-2 adalah jenis auksin, yang terdiri tiga taraf, yaitu IAA, NAA dan IBA, dengan konsentrasi yang sama yaitu $0.5 \mathrm{mg} \mathrm{L}^{-1}$, sehingga terdapat 6 perlakuan yang disusun menggunakan rancangan acak lengkap (RAL). Setiap perlakuan diulang sebanyak 5 kali, sehingga terdapat 30 satuan percobaan dan setiap satuan percobaan terdiri satu botol dengan satu eksplan. Eksplan yang digunakan adalah planlet yang tumbuh percobaan perkecambahan ES. Pengamatan dilakukan terhadap peubah pertumbuhan tunas dan akar sampai pada minggu ke-4 setelah tanam.

\section{HASIL DAN PEMBAHASAN}

\section{Proliferasi Kalus Embriogenik}

Proliferasi kalus embriogenik merupakan salah satu tahap ES yang bertujuan untuk memperbanyak ES fase globular. Pada percobaan ini kalus diperbanyak pada media dasar MS + vitamin MW + $500 \mathrm{mg} \mathrm{L}^{-1}$ ekstrak malt dengan penambahan bahan pemadat Phytagel sesuai dengan perlakuan. Hasil percobaan menunjukkan bahwa eksplan yang ditanam menghasilkan ES fase globular dengan jumlah yang berbeda-beda antar konsentrasi Phytagel yang digunakan. Pada Tabel 1 dapat dilihat bahwa Phytagel $2.5 \mathrm{mg}$ $\mathrm{L}^{-1}$ menghasilkan ES terbanyak, sedangkan kenaikan konsentrasi sampai $4.0 \mathrm{mg} \mathrm{L}^{-1}$ mengakibatkan penurunan jumlah ES fase globular yang terbentuk. Zhang et al. (2010) juga mendapatkan hasil yang sama pada induksi ES pada tanaman kapas. Peningkatan kekerasan media dapat mengurangi terbentuknya ES fase globular, bahkan dapat mengurangi jumlah ES karena membentuk ES fase yang lebih dewasa (Husain et al., 2015).

Jumlah ES fase globular yang dihasilkan pada perlakuan Phytagel $2.5 \mathrm{~g} \mathrm{~L}^{-1}$ berbeda nyata dengan konsentrasi $3 \mathrm{~g} \mathrm{~L}^{-1}, 3.5$ $\mathrm{g} \mathrm{L}^{-1}$, dan $4 \mathrm{~g} \mathrm{~L}^{-1}$ pada minggu pertama dan ke-7. Uji F menunjukkan bahwa pada minggu ke-3 dan ke-5 antar perlakuan Phytagel tidak ada perbedaan, namun demikian jumlah ES fase globular yang dihasilkan perlakuan Phytagel $2.5 \mathrm{~g} \mathrm{~L}^{-1}$ adalah yang terbaik. Tabel 1 menunjukkan bahwa perlakuan Phytagel $2.5 \mathrm{~g}$ $\mathrm{L}^{-1}$ memiliki jumlah ES fase globular terbanyak pada setiap minggu pengamatan. Embrio somatik fase globular juga dapat berkembang membentuk ES dewasa yaitu fase jantung, fase torpedo, dan fase kotiledon. 
Tabel 1. Pengaruh konsentrasi Phytagel terhadap jumlah ES fase globular eksplan kalus embriogenik yang dihasilkan perlakuan kolkisin.

\begin{tabular}{ccccc}
\hline \multirow{2}{*}{$\begin{array}{c}\text { Perlakuan } \\
\text { Phytagel } \\
\left(\mathrm{gr} \mathrm{L}^{-1}\right)\end{array}$} & \multicolumn{4}{c}{$\begin{array}{c}\text { ES Fase Globular pada } \\
\text { Minggu ke- }\end{array}$} \\
\cline { 2 - 5 } & 1 & 3 & 5 & 7 \\
\hline 2.5 & $17.6 \mathrm{a}$ & 16.0 & 16.6 & $18.8 \mathrm{a}$ \\
3.0 & $8.0 \mathrm{~b}$ & 11.6 & 14.6 & $7.8 \mathrm{~b}$ \\
3.5 & $13.6 \mathrm{ab}$ & 11.0 & 12.0 & $10.4 \mathrm{~b}$ \\
4.0 & $9.8 \mathrm{~b}$ & 12.6 & 12.8 & $10.8 \mathrm{~b}$ \\
\hline Uji F & $*$ & tn & tn & $*$ \\
\hline
\end{tabular}

Keterangan: Angka pada kolom yang sama, diikuti oleh huruf yang berbeda menunjukkan berbeda nyata pada taraf $\alpha=5 \%$ (uji DMRT) dengan menggunakan transformasi data $\sqrt{x+0.5}$

Kalus dengan perlakuan Phytagel $3.0 \mathrm{~g}$ $\mathrm{L}^{-1}$ menghasilkan ES fase globular paling banyak pada minggu ke-5 yaitu rata-rata 14.6 dan kemungkinan berkembang ke ES dewasa pada minggu ke-7. Hal ini ditunjukkan oleh penurunan jumlah ES fase globular $14.6 \mathrm{ke}$ 7.8. Perlakuan Phytagel $3.5 \mathrm{~g} \mathrm{~L}^{-1}$ menghasilkan ES fase globular terbanyak pada minggu pertama dan Phytagel $4.0 \mathrm{~g} \mathrm{~L}^{-1}$ terbanyak pada minggu ke-5. Kedua perlakuan konsentrasi Phytagel $3.5 \mathrm{~g} \mathrm{~L}^{-1}$ dan $4.0 \mathrm{~g} \mathrm{~L}^{-1}$ ini kemungkinan juga menunjukkan perkembangan ES fase globular ke ES fase yang lebih dewasa. Hal ini ditunjukkan dengan penurunan jumlah ES pada minggu berikutnya pada kedua perlakuan tersebut. Hasil secara keseluruhan menunjukkan bahwa ES fase globular paling banyak dihasilkan pada Phytagel $2.5 \mathrm{~g} \mathrm{~L}^{-1}$.

Konsentrasi Phytagel $2.5 \mathrm{~g} \quad \mathrm{~L}^{-1}$ merupakan konsentrasi yang optimum dengan tingkat kepadatan yang tepat sehingga cekaman air pada media tidak tinggi dan unsur-unsur hara yang dibutuhkan eksplan dapat diserap dengan baik. Pemadat Phytagel $2.5 \mathrm{~g} \mathrm{~L}^{-1}$ juga baik untuk mempertahankan ES pada fase globular dan tidak berkembang cepat menjadi ES dewasa. Media dengan peningkatan konsentrasi Phytagel akan menurunkan potensial matriks media sehingga ketersediaan air untuk diserap berkurang dan menyebabkan kandungan air dalam ES menjadi rendah, kondisi ini baik untuk pendewasaan ES (Kosmiatin et al., 2014). Media dengan konsentrasi pemadat yang lebih tinggi akan lebih baik digunakan untuk pendewasaan ES pada untuk proliferasi kalus embriogenik.

Perbedaan respon pembentukan ES fase globular pada perlakuan Phytagel dapat dilihat pada Gambar 4. Kalus dengan perlakuan Phytagel $2.5 \mathrm{~g} \mathrm{~L}^{-1}$ (Gambar 4.b) lebih banyak menghasilkan ES fase globular yang ditunjukkan dengan adanya spot hijau, dibandingkan kalus dengan perlakuan Phytagel pada konsentrasi yang lain. Kalus dengan perlakuan Phytagel $3.0 \mathrm{~g} \mathrm{~L}^{-1}$ (Gambar 4.c) terlihat tidak sebaik pada Phytagel $3.5 \mathrm{~g}$ $\mathrm{L}^{-1}$ (Gambar 4.d) dan Phytagel $4.0 \mathrm{~g} \mathrm{~L}^{-1}$ relatif sama dalam membentuk ES fase globular (Gambar 4.e). Embrio somatik fase dewasa (fase jantung, fase torpedo, dan fase kotiledon) dapat langsung terbentuk semua perlakuan terutama pada media dengan konsentrasi Phytagel lebih tinggi. Hal ini menguntungkan karena proliferasi dan pendewasaan embrio dapat berlangsung dalam satu tahap kultur.

\section{Pendewasaan Embrio Somatik}

Pendewasaan ES merupakan perkembangan ES fase globular sampai menjadi ES fase kotiledon. Pendewasaan ES merupakan tahapan penting dalam keberhasilan embriogenesis somatik (Kosmiatin et al., 2014). Pendewasaan ES pada tanaman jeruk sangat tergantung pada jenis dan konsentrasi zat pengatur tumbuh (Husni et al., 2010).

Tabel 2 menunjukkan bahwa media pendewasaan ES dengan perlakuan ABA berpengaruh terhadap pembentukan ES fase jantung. Pada minggu ke-5 menunjukkan bahwa perlakuan ABA $0.5 \mathrm{mg} \mathrm{L}^{-1}$ berbeda nyata dibandingkan dengan perlakuan konsentrasi ABA lainnya. Pada minggu ke-7 dan ke-9 ES fase jantung yang terbentuk tidak berbeda nyata antar perlakuan. Perlakuan ABA $0.5 \mathrm{mg}$ $\mathrm{L}^{-1}$ memiliki jumlah ES fase jantung terbanyak. Walaupun eksplan awal yang ditanam berjumlah 5 ES fase globular, namun pada minggu ke-5 dan seterusnya, telah berkembang ES baru yang kemungkinan merupakan embrio somatik sekunder (Kiong et al., 2008). Tabel 2 juga menunjukkan bahwa penambahan $0.5 \mathrm{mg} \mathrm{L}^{-1} \mathrm{ABA}$ menghasilkan ES fase jantung terbaik. Embrio somatik fase jantung yang terbentuk berkembang ke fase selanjutnya pada minggu ke-9.

Perlakuan ABA tidak berpengaruh nyata terhadap pembentukan ES fase torpedo 
dan ES fase kotiledon. Tabel 2 menunjukkan bahwa penambahan $0.5 \quad \mathrm{mg} \quad \mathrm{L}^{-1}$ ABA cenderung menghasilkan ES fase torpedo dan ES fase kotiledon terbaik. Setiap minggu ES fase torpedo yang dihasilkan bertambah dan berkurang. Hal ini karena ES fase torpedo berkembang menjadi kotiledon atau berdediferensiasi menjadi kalus kembali. Pada umur tujuh minggu setelah kultur (MSK) jumlah rata-rata ES fase torpedo pada perlakuan ABA $0.5 \mathrm{mg} \mathrm{L}^{-1}$ adalah yang terbanyak. Media pendewasaan dengan perlakuan ABA $0.3 \mathrm{mg} \mathrm{L}^{-1}$ menghasilkan ES fase torpedo terbaik pada minggu ke-5, sedangkan perlakuan $\mathrm{ABA} 0.1 \mathrm{mg} \mathrm{L}^{-1}$ dan media tanpa ABA menghasilkan ES fase torpedo yang sama pada minggu ke-9.

Embrio somatik fase kotiledon mulai terbentuk pada minggu ke-5 dan meningkat pada minggu ke-9. Tabel 2 menunjukkan bahwa jumlah ES fase kotiledon pada 9 MSK meningkat sangat cepat. Perkembangan ES membentuk fase jantung, torpedo, dan kotiledon meningkat seiring dengan penambahan konsentrasi ABA. Pemberian ABA berkonsentrasi $0.5 \mathrm{mg} \mathrm{L}^{-1}$ menghasilkan ES fase jantung, fase torpedo, dan fase kotiledon terbaik. Husni et al. (2010) juga mendapatkan konsentrasi ABA yang sama untuk pendewasaan ES jeruk siam Simadu. Pada penelitian ini persentase pendewasaan yang terbaik adalah jika ES fase globular ditanam pada media dengan penambahan ABA $0.5 \mathrm{mg} \mathrm{L}^{-1}$ yaitu sebesar $82 \%$.

Pemberian ABA bertujuan untuk menyeragamkan fase pendewasaan sehingga didapatkan ES fase kotiledon yang siap dikecambahkan (Benelli et al., 2010; Cordoza dan D'Souza, 2002). Pemberian ABA juga dapat menekan terjadinya pertumbuhan embrio yang prematur (Merigo, 2011). Jumlah ratarata ES fase jantung berkisar 5.5-7.6, ES fase torpedo 0.1-0.6, dan ES fase kotiledon 3.0-4.1. Rata-rata jumlah ES fase torpedo lebih sedikit dibandingkan dengan jumlah ES fase jantung, dan ES fase kotiledon. Hal ini menunjukkan bahwa ES fase jantung berkembang ke fase kotiledon. Fase jantung (Gambar 4.f) merupakan struktur awal pembentukkan ES fase kotiledon dimana fase ini memiliki struktur awal bipolar, yang akan berkembang menjadi fase terpedo (Gambar 4.g). Pada saat ES fase torpedo terbentuk, sel akan mengarahkan pertumbuhannya ke arah bawah dan membentuk meristem akar yang ditandai dengan terbentuknya struktur akar. Pendewasaan embrio somatik akan berakhir pada bentuk kotiledon sempurna (Gambar 4.h) dimana meristem akar dan meristem tunas mulai terbentuk (Agisimanto et al., 2011).

Perlakuan ABA $0.5 \mathrm{mg} \quad \mathrm{L}^{-1}$ pada minggu ke-9 didapatkan ES fase kotiledon yang banyak, namun sebagian ES memiliki morfologi abnormal karena memiliki ukuran yang lebih besar ES fase kotiledon normal (Gambar 4.i). Morfologi abnormal ini diduga karena adanya akumulasi protein yang berlebih pada aktivitas biotin yang terdapat pada formulasi vitamin MW serta ekstrak malt sebagai bahan organik yang mudah diserap oleh tanaman (Dodeman at al., 1997). Akumulasi protein yang berlebih akan menghambat akumulasi protein LEA (Late Embryogenesis Abundant) yang berperan dalam pendewasaan ES sehingga ES menjadi abnormal.

Tabel 2. Rata-rata jumlah ES fase jantung, fase torpedo dan fase kotiledon yang terbentuk dari lima eksplan awal ES fase globular jeruk keprok Batu 55 sampai minggu ke-9 setelah kultur pada media pendewasaan dengan penambahan ABA.

\begin{tabular}{cccccccccc}
\hline \multirow{2}{*}{$\begin{array}{c}\text { Konsentrasi ABA } \\
\left(\mathrm{mg} \mathrm{L}^{-1}\right)\end{array}$} & \multicolumn{10}{c}{ Minggu ke- } \\
\cline { 2 - 11 } & FJ & FT & FK & FJ & FT & FK & FJ & FT & FK \\
\hline 0.0 & $4.5 \mathrm{ab}$ & 0.3 & 0.5 & 6.3 & 0.3 & 1.0 & 5.5 & 0.2 & 3.0 \\
0.1 & $2.8 \mathrm{~b}$ & 0.2 & 0.3 & 6.5 & 0.2 & 0.8 & 5.2 & 0.2 & 2.8 \\
0.3 & $4.1 \mathrm{ab}$ & 0.2 & 0.3 & 8.5 & 0.3 & 0.5 & 6.2 & 0.3 & 3.3 \\
0.5 & $7.3 \mathrm{a}$ & 0.2 & 0.7 & 11 & 0.8 & 1.0 & 7.6 & 0.7 & 4.2 \\
\hline Uji F & $*$ & tn & tn & tn & tn & tn & tn & tn & tn \\
\hline
\end{tabular}

Keterangan: FJ: Fase Jantung; FT: Fase Torpedo; FK: Fase Kotiledon. Angka pada kolom yang sama, diikuti oleh huruf yang berbeda menunjukkan berbeda nyata pada taraf $\alpha=5 \%$ (uji DMRT) dengan menggunakan transformasi data $\sqrt{x+0.5}$. 


\section{Perkecambahan Embrio Somatik}

Perkecambahan ES merupakan proses yang terjadi setelah fase pendewasaan. Perkecambahan sangat dipengaruhi oleh beberapa faktor seperti faktor lingkungan sepert suhu dan cahaya, serta komposisi ZPT yang terdapat pada media perkecambahan (Merigo, 2011). Jenis vitamin juga berpengaruh terhadap perkecambahan ES (Kosmiatin et al., 2015). Pada Gambar 1 (a) terlihat bahwa perlakuan vitamin MW menghasilkan persentase kecambah lebih baik dibandingkan dengan perlakuan vitamin MS. Persentase kecambah yang diamati merupakan gabungan antara kecambah normal dan abnormal. Persentase kecambah yang dihasilkan pada perlakuan vitamin MW adalah sebesar 67.2-85.9\%, sedangkan persentase kecambah yang dihasilkan pada perlakuan vitamin MS sebesar 55.4$80.1 \%$. Peningkatan persentase kecambah pada perlakuan vitamin MW cenderung lebih stabil dibandingkan dengan perlakuan vitamin MS pada minggu ke-2 sampai minggu ke-6.

Gambar 1 (b) menunjukkan bahwa perkecambahan yang sempurna, yaitu menghasilkan planlet mulai terjadi pada minggu ke-4. Perlakuan vitamin MW menghasilkan planlet sebesar $5.2 \%$, sedangkan perlakuan vitamin MS menghasilkan planlet sebesar 4.3\% ES yang berkecambah. Peningkatan jumlah planlet terus terjadi sampai minggu ke10, dimana perlakuan penambahan vitamin MS menghasilkan planlet sebanyak $43.1 \%$, sedangkan penambahan dengan vitamin MW memilik persentase sebanyak $39.2 \%$. Penelitian Merigo (2011) menghasilkan planlet dengan persentase sebanyak $84 \%$ dengan perlakuan $\mathrm{GA}_{3} \quad 2.5 \mathrm{mg} \mathrm{L}^{-1}$. Rendahnya persentase ES fase kotiledon yang membentuk planlet pada percobaan ini diduga karena adanya keragaman jumlah kromosom pada eksplan yang digunakan.

Gambar 2 menunjukkan bahwa penambahan vitamin MW menghasilkan kecambah abnormal lebih banyak dibandingkan kecambah normal, yaitu sebesar $45.5 \%$ dan $39.2 \%$, sedangkan penambahan vitamin MS menghasilkan kecambah normal yang lebih banyak dibandingkan kecambah abnormal $43.1 \%$ dan $36.9 \%$.

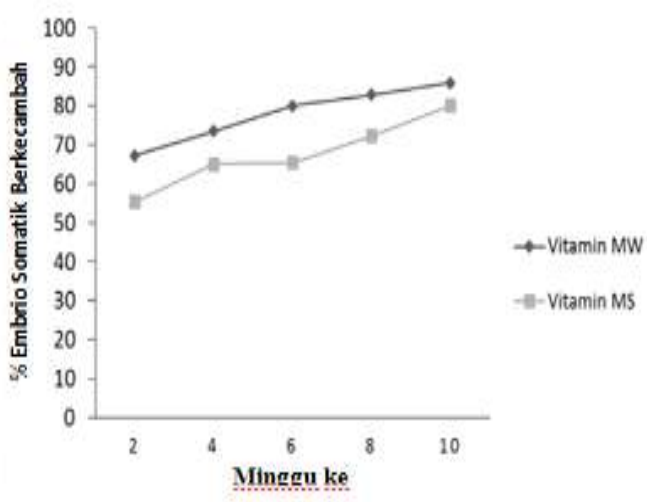

(a)

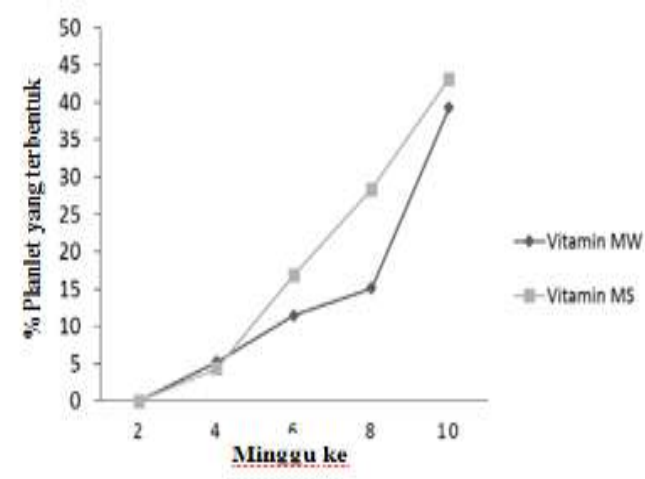

(b)

Gambar 1. Pengaruh jenis vitamin terhadap (a) persentase embrio somatik yang berkecambah dan (b) persentase planlet yang terbentuk.

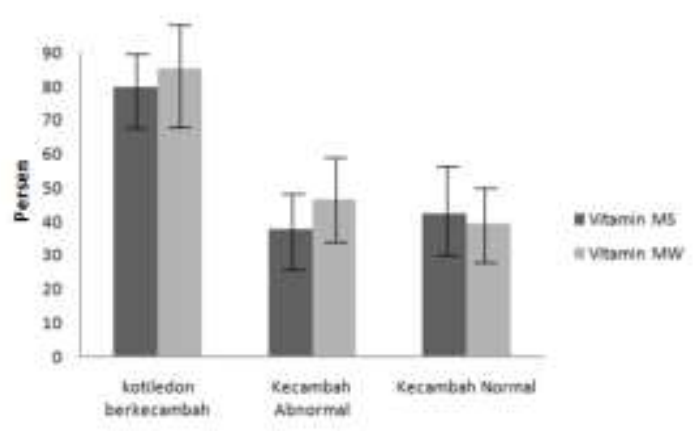

Gambar 2. Pengaruh penambahan vitamin pada media perkecambahan ES jeruk keprok Batu 55 hasil perlakuan kolkisin terhadap persentase kecambah normal dan abnormal. 
Kecambah normal adalah ES yang tumbuh membentuk tunas dan akar. ES fase kotiledon sebagian besar membentuk akar yang normal, sedangkan tunas yang terbentuk sebagian besar abnormal. Hal ini disebabkan meristem pucuk tidak berkembang dengan baik, dan hilangnya bipolaritas (Benelli et al., 2010; Quiroz-Figuroa et al., 2006; Lelu et al., 1994), oleh karena itu, ES fase kotiledon harus ditanam pada media yang dapat menginduksi merestem pucuk lebih responsif (El Dawayati et al., 2012). Gambar 4 memperlihatkan bahwa media perkecambahan dengan perlakuan vitamin MW menghasilkan tunas yang lebih tinggi (Gambar 4.k) dibandingkan dengan tunas pada media dengan perlakuan vitamin MS (Gambar 4.j). Hal ini karena vitamin MW memiliki komposisi yang lebih lengkap dibandingkan dengan vitamin MS, sehingga pertumbuhan jaringan pada tunas akan lebih baik. Planlet yang telah terbentuk kemudian dipindahkan ke media tanpa ZPT agar pertumbuhan sel yang terjadi secara cepat dapat dikurangi (Merigo, 2011).

\section{Pertumbuhan Tunas dan Akar}

Proses pemanjangan tunas dan pertumbuhan akar bertujuan untuk mengoptimalkan ukuran planlet agar dapat tumbuh pada saat aklimatisasi in vivo. Ukuran planlet dioptimalkan dengan menanam pada media yang ditambahkan vitamin dan ZPT. Vitamin yang digunakan adalah vitamin $\mathrm{MS}$ dan vitamin MW, sedangkan ZPT yang digunakan adalah NAA, IAA, IBA dengan konsentrasi $0.5 \mathrm{mg} \mathrm{L}^{-1}$.

Hasil analisis data secara statistik menunjukkan tidak ada interaksi antara vitamin dan ZPT yang diberikan. Zat pengatur tumbuh secara tunggal berpengaruh nyata terhadap pertambahan tinggi tunas dan tidak berpengaruh nyata terhadap pertambahan panjang akar. Perlakuan vitamin secara statistik juga tidak berpengaruh terhadap pertambahan tinggi tunas dan panjang akar. Uji lanjut dengan Duncan Multiple Range Test (DMRT) pada selang kepercayaan $95 \%$ menunjukkan bahwa IBA berkonsentrasi $0.5 \mathrm{mg} \mathrm{L}^{-1}$ adalah yang terbaik untuk meningkatkan pertumbuhan tunas (Tabel 3).

Tabel 3 dan Gambar 3 (a) menunjukkan bahwa perlakuan vitamin MS lebih baik dalam meningkatkan pertumbuhan tunas dibandingkan dengan perlakuan vitamin MW. Media dasar dengan perlakuan IBA $0.5 \mathrm{mg} \mathrm{L}^{-1}$ juga memperlihatkan pengaruh yang lebih baik pada pertambahan tinggi tunas dibandingkan perlakuan NAA dan IAA.

Tabel 3. Pengaruh ZPT terhadap pertambahan tinggi tunas dan pertambahan panjang akar pada 4 MST.

\begin{tabular}{|c|c|c|}
\hline Perlakuan & $\begin{array}{l}\text { Pertambahan } \\
\text { Tinggi } \\
\text { Tunas }(\mathrm{cm}) \\
\end{array}$ & $\begin{array}{l}\text { Pertambahan } \\
\text { Panjang Akar } \\
\text { (cm) }\end{array}$ \\
\hline \multicolumn{3}{|l|}{ Vitamin } \\
\hline MS & 0.44 & 0.21 \\
\hline MW & 0.34 & 0.26 \\
\hline Uji F & tn & tn \\
\hline \multicolumn{3}{|l|}{ ZPT } \\
\hline NAA & $0.28 \mathrm{~b}$ & 0.19 \\
\hline IAA & $0.29 \mathrm{~b}$ & 0.22 \\
\hline IBA & $0.59 \mathrm{a}$ & 0.31 \\
\hline Uji F & $*$ & tn \\
\hline Interaksi & tn & tn \\
\hline $\begin{aligned} \text { Keterangan: } & \mathrm{A} \\
& \text { ol } \\
& \text { be } \\
& \mathrm{D} \\
& \text { tr }\end{aligned}$ & $\begin{array}{l}\text { Ingka pada kolom } \\
\text { leh huruf yang ber } \\
\text { erbeda nyata pada } \\
\text { OMRT) dengan } \\
\text { ransformasi data } \sqrt{x}\end{array}$ & $\begin{array}{l}\text { yang sama, diikuti } \\
\text { beda menunjukkan } \\
\text { taraf } \alpha=5 \% \text { (uji } \\
\text { menggunakan } \\
+0.5 \text {. }\end{array}$ \\
\hline
\end{tabular}

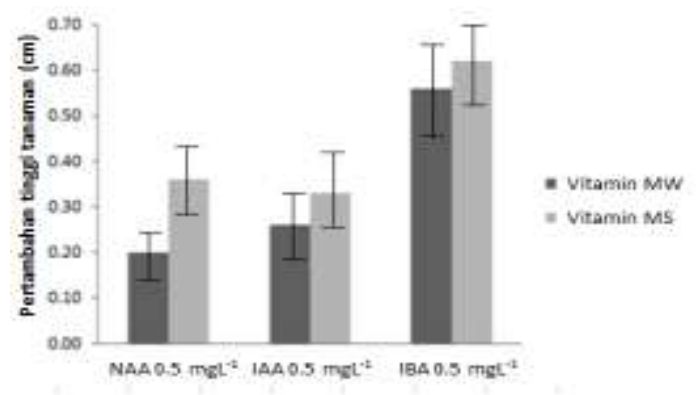

(a)

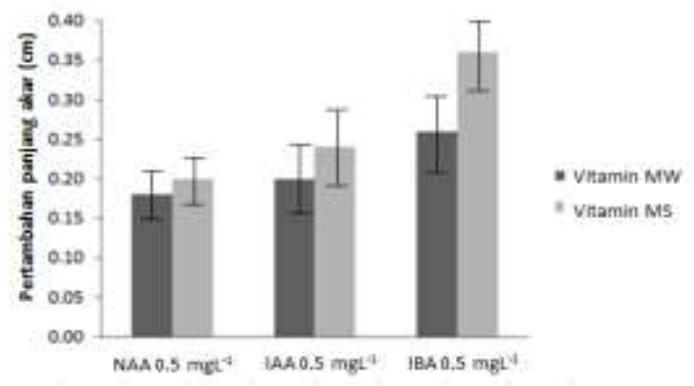

(b)

Gambar 3. Pengaruh vitamin dan ZPT terhadap pertambahan tinggi tunas (a) dan pertambahan panjang akar (b) pada 4 MST. 

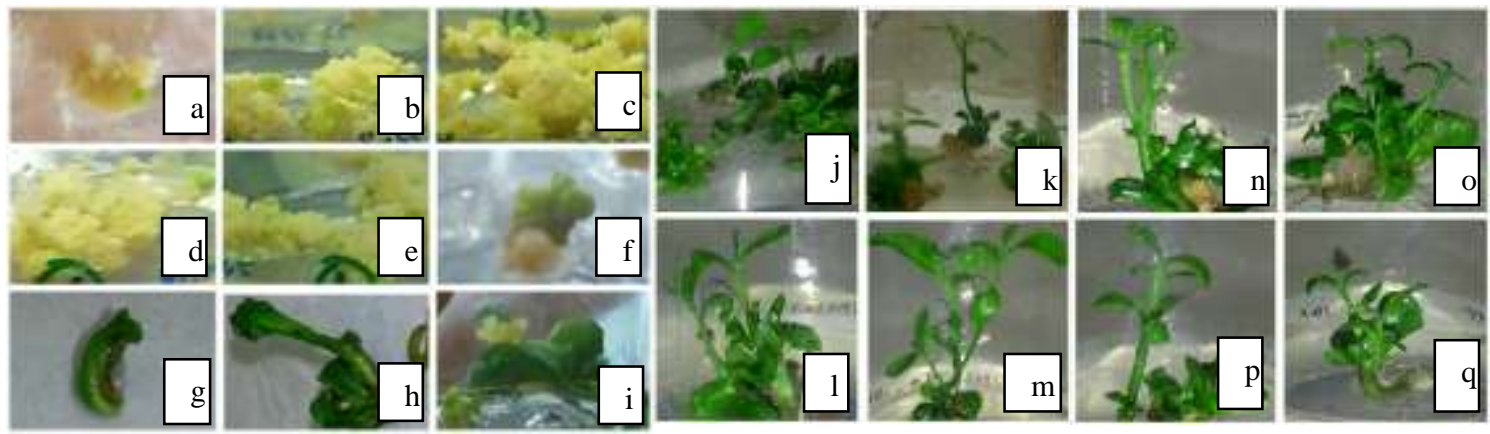

Gambar 4. Induksi embriogenesis somatik tanaman jeruk keprok cv Batu 55. Proliferasi kalus (a) terbentuknya ES fase globular, (b) perlakuan Phytagel $2.5 \mathrm{~g} \mathrm{~L}^{-1}$, (c) perlakuan Phytagel $3.0 \mathrm{~g} \mathrm{~L}^{-1}$, (d) perlakuan Phytagel $3.5 \mathrm{~g} \mathrm{~L}^{-1}$, (e) perlakuan Phytagel $4.0 \mathrm{~g} \mathrm{~L}^{-1}$ ). Pendewasaan ES (f) fase jantung, (g) fase torpedo, (h) fase kotiledon normal, (i) kotiledon abnormal. Perkecambahan ES dewasa (j) planlet pada perlakuan vitamin MS, (k) planlet pada perlakuan vitamin MW. Pemanjangan akar dan tunas, perlakuan vitamin MS (l) NAA, (m) IBA, (n) IAA. Perlakuan vitamin MW (o) NAA, (p) IAA, dan (q) IBA.

Tumbuhnya tunas adventif pada planlet terjadi pada media dasar dengan vitamin MW (Gambar 4. o, p, q) lebih banyak dibandingkan pada vitamin MS (Gambar 4. 1, m, n) Hal ini diduga karena pada vitamin MW terdapat biotin yang dapat meningkatkan terjadinya multiplikasi tunas. Menurut Merigo (2011) biotin yang ditambahkan pada media dasar MS dapat meningkatkan multiplikasi tunas adventif, sehingga tunas yang dihasilkan menjadi lebih banyak.

\section{KESIMPULAN}

Proliferasi kalus embriogenik dapat menghasilkan jumlah ES fase globular dengan baik pada media dasar MS vitamin MW +500 $\mathrm{mg} \mathrm{L}^{-1}$ ekstrak malt dengan pemadat Phytagel berkonsentrasi $2.5 \mathrm{~g} \mathrm{~L}^{-1}$. Pendewasaan ES dengan media dasar MS vitamin MW + 100 $\mathrm{mg} \mathrm{L}^{-1}$ ekstrak malt + ABA $0.5 \mathrm{mg} \mathrm{L}^{-1}$ dapat menghasilkan ES fase kotiledon yang terbaik. Media dasar MS + vitamin MS + $\mathrm{GA}_{3} 2.5 \mathrm{mg}$ $\mathrm{L}^{-1}+100 \mathrm{mg} \mathrm{L}^{-1}$ ekstrak malt merupakan media terbaik untuk mengecambahkan ES fase kotiledon menjadi planlet dengan persentase $43.1 \%$. Pertumbuhan tunas dan akar lebih baik pada media dasar MS + vitamin MS + $0.5 \mathrm{mg}$ $\mathrm{L}^{-1} \mathrm{IBA}+500 \mathrm{mg} \mathrm{L}^{-1}$ ekstrak malt.

\section{SARAN}

Perlu dilakukan pengujian ploidi pada planlet yang terbentuk untuk melihat keberhasilan poliploidisasi dengan kolkisin. Embrio somatik yang jumlah ploidinya tidak diketahui membuat hasil regenerasi cukup beragam, sebaiknya jumlah ploidi dapat diketahui sebelum diregenerasikan.

\section{DAFTAR PUSTAKA}

Agisimanto, D., N.M. Noor, R. Ibrahim, A. Mohamad. 2011. Efficient somatic embryo production of limau madu (Citrus suhuiensis Hort. ex Tanaka) in liquid culture. African J. of Biotech. 11(12): 2879-2888.

Al-Taha, H.A.K., A.M. Jasim, M.F. Abbas. 2012. Somatic embryogenesis and plantlet regeneration from nucleus tissues of local orange (Citrus sinensis (L.) Osbeck). Acta Agric. Slovenica. 99(2): 185-189.

Amin, H., A. Shekafandeh. 2015. Somatic embryogenesis and plant regeneration from juice vesicles of Mexican Lime (Citrus aurantifolia L.). Jordan Journal of Agricultural Sciences. 11(2): 495-503. 
Benelli, C., M.A. Germana, T. Ganino, D. Beghe. 2010. Morphological and anatomical observations of abnormal somatic embryos from anther cultures of Citrus reticulata. Biol. Plant. 54(2): 224-230.

Button, J., C.H. Bornman. 1971. Development of nucellar plants from unpollinated and unfertilized ovules of the Washington Navel Orange in vitro. J. S. Afr. Bot. 37: 127-134.

Cardoza, V., L. D’Souza. 2002. Induction, development and germination of somatic embryos from nucellar tissues of cashew (Anacardium occidentale L.). Sci. Hort. 93(3-4): 367-372.

Carimi, F., F. DePasquale, F.G. Crescimanno. 1995. Somatic embryogenesis in citrus from styles culture. Plant Sci. 105: 8186.

Carra, A., F. De Pasqualez, A. Ricci, F. Carimi. 2006. Diphenylurea derivatives induced somatic embryogenesis in citrus. Plant Cell Tiss. Cult. 87: 41-48.

Chawla, H.S. 2009. Introduction to Biotechnology. Oxford \& IBH Publishing Company Pvt. Limited.

Devy, N.F., Yenni, Hardiyanto. 2014. The growth performance of citrus derived from somatic embryogenesis plantlet and scion stock. Indones. J. Agric. Sci. 15(2): 71-78.

Dewi, I.S., G.S. Jawak, B.S. Purwoko. 2014. Respon pertumbuhan kultur in vitro jeruk besar (Citrus maxima (Burm.) Merr.) cv Nambangan terhadap osmotikum dan retardan. J. Hort. Indonesia. 5(1): 21-28.

Dodeman, V.L., G. Ducreux, M. Kreis. 1997. Zygotic embryogenesis versus somatic embryogenesis. J. Exp. Bot. 48: 1493-1509.

El Dawayati, M.M., O.H.A. EL Bar, Z.E. Zaid, A.F.M.Z. El Din. 2012. In vitro morpho-histological studies of newly developed embryos from abnormal malformed embryos of date palm cv. Gundila under desiccation effect of polyethelyne glycol treatments. Annals Agric. Sci. 57(2): 117-128.

El-Sawy, A., A. Gomaa. M.H. Abd-El-Zaher, A. Reda, N. Danial. 2013. Production of Somatic embryogenesis via in vitro culture of stigma and style for elimination of Citrus Psorosis Virus $(\mathrm{CpsV})$ from some Citrus genotypes. J. of Hort. Sci. \& Ornamental Plants. 5(2): 110-117.

Gholami, A.A., S.V. Alavi, A. Majd, F. Fallahian. 2013. Plant regeneration through direct and indirect somatic embryogenesis from immature seeds of citrus. Europ. J. Expt. 3(3): 307-310.

Gill, M.I.S., Z. Singh, B.S. Dhillon, S.S Gosal. 1995. Somatic embryogenesis and plant regeneration in mann (Citrus reticulata Blanco). Sci. Hort. 63: 167174.

Gopitha, K., L. Bhavani, J. Senthilmanickam. 2010. Effect of the different auxins and cytokinins in callus induction, shoot, root regeneration in sugarcane. Intl. J. of Pharma and Bio Sci. 1: 3-11.

Hidaka, T., Y. Yamada, T. Shichijo. 1981 Plantlet formation from anthers of Citrus aurantium L. Proc. Int. Soc. Citriculture. 1: 153-155.

Husain, I., F.N. Utami, A. Purwito, A. Husni, K.H. Mutaqin, H. Susanto. 2015. Plantlet regeneration via somatic embryogenesis from mature seed of Citrus nobilis variety SoE from SoE NTT. Hort. Biotech. Res. 1: 23-29.

Husni, A., A. Purwito, I. Mariska, D Sudarsono. 2010. Regenerasi jeruk Siam melalui embriogenesis somatik. J. Agro. Biogen. 6: 75-83.

Kasprzyk-Pawelec, A., J. Pietrusiewicz, E. Szczuka. 2015. In vitro regeneration induced in leaf explants of Citrus limon L. Burm cv. 'Primofiore'. Acta Sci. Pol. Hortorum Cultus. 14(4): 143-153. 
Kiong, A.L.P., L.S. Wan, S. Hussain, R. Ibrahim. 2008. Induction of somatic embryos from explants different of Citrus sinensis. J. Sci. 3: 18-32.

Kosmiatin, M., A. Purwito, G.A. Wattimena, I. Mariska. 2014. Induksi embriogenesis somatik jaringan endosperma jeruk siam (Citrus nobilis Lour.) cv Simadu. J. Agron. Indonesia. 42(1): 44-51.

Lelu, M.A., C. Bastien, K. Klimaszewska, C. Ward, P.J. Charest. 1994. An improved method for somatic plantlet production in hybrid larch (Larix X leptoeuropaea). Part 1. Somatic embryo maturation. Plant Cell.Tiss. Org. Cult. 36: 107-15.

Martasari, C. 2008. Teknologi perbaikan jeruk tanpa biji. http://balitjestro.litbang.deptan. go.id/id/599.html. [25 Februari 2014]

Meneses, A., D. Flores, M. Munoz, G. Arrieta, A.M. Espinoza. 2005. Effect of 2,4-d, hydric stress and light on indica rice (Oryza sativa) somatic embryogenesis. Rev. Biol. Trop. 53(3-4): 361-8.

Merigo, J.A. 2011. Studi regenerasi tanaman jeruk keprok Batu 55 (Citrus reticulata L.) melalui jalur embriogenesis somatik. Tesis. Program Pascasarjana. Institut Pertanian Bogor. Bogor.

Meziane, M., M. Boudjeniba, D. Frasheri, S. Boukhalfa, S. Braneci. 2012. Regeneration of Algerian citrus germplasm by stigma/style somatic embryogenesis. Afr. J. Biotec. 11(25): 6666-6672.

Mohamed, E.S.A., A. Gomaa, N. Danial. 2014. In vitro regeneration and somatic embryogenesis in citrus. Plant Tiss. Cult. \& Biotech. 24(2): 247-262.

Morel, G., R.H. Wetmore. 1951. Fern callus tissue culture. Am. J. Bot. 38: 141-143.
Murashige, T., F. Skoog. 1962. A revised medium for rapid growth and bioassays with tobacco tissue cultures. Physiol. Plant. 15(3): 473-497.

Nito, N., M. Iwamasa. 1990. In vitro plantlet formation from juice vesicle callus of Satsuma (Citrus unshiu Mare.). Plant Cell, Tiss. Org. Cult. 20(2): 137-140.

Pasquali, G., S. Biricolti. 2004. In vitro culture of ovules with nucelli and embryos of citrus. Adv. Hort.Sci. 18(1): 11-14.

Quiroz-Figueroa, F., R. Rojas-Herrera, R.M. Galaz-Avalos, V.M. Loyola-Vargas. 2006. Embryo production through somatic embryogenesis can be used to study cell differentiation in plants. Plant Cell, Tiss. Org. Cult. 86(3): 285-301. DOI: $10.1007 / \mathrm{s} 11240-006-9139-6$.

Rangan, T.S., T. Murashige, W.P. Bitters. 1968. In vitro initiation of nucellar embryos in monoembryonic citrus. Hort.Sci. 3(4): 226-227.

Starrantino, A., F. Russo. 1980. Seedlings from undeveloped ovules of ripe fruits of polyembryonic citrus cultivars. Hort.Sci. 15(3): 296-297.

Suyamto, A. Supriyanto, A. Agustian, A. Triwiratno, M. Winarno. 2005. Prospek dan Arah Pengembangan Agribisnis Jeruk. Badan Penelitian dan Pengembangan Pertanian. Departemen Pertanian 235 p. Jakarta.

Yulianti, F., A. Purwito, A. Husni, D. Dinarti. 2014. Induksi tetraploid tunas pucuk jeruk siam Simadu (Citrus nobilis Lour.) menggunakan kolkisin secara in vitro. J. Agron. Indonesia. 42(2): 144-150.

Zhang, Q., J. Wang, J. Lin, S.F.F. Yan, D.P. Wu, L. Qin, J.H. Chen, C.X. Hong, S.J. Zhu. 2010. Effects of different gelling agents on the somatic embryogenesis and plant regeneration in upland cotton. Cotton Sci. 22(1): 3-9. 